Island Studies Journal, Vol. 10, No. 1, 2015, pp. 15-30

\title{
The Dutch Caribbean municipalities in comparative perspective
}

\author{
Wouter P. Veenendaal \\ KITLV / Royal Netherlands Institute of Southeast Asian and Caribbean Studies \\ Leiden, The Netherlands \\ veenendaal@kitlv.nl
}

\begin{abstract}
Upon the dissolution of the Netherlands Antilles in 2010, the smallest islands in this federation - Bonaire, St. Eustatius, and Saba - became special municipalities of the Netherlands, and were hence politically and constitutionally integrated into the Dutch metropolis. The present article seeks to understand this development in the context of the broader academic literature on small, non-sovereign island jurisdictions in the Caribbean and elsewhere. After a description of the reforms and a discussion of the perceived benefits and drawbacks of the new political status, the newly created Dutch Caribbean municipalities are compared with other non-sovereign jurisdictions in the Caribbean. Whereas the choice for political integration in itself can be compared with the French postwar policy of départementalisation, in terms of the historical significance and the direction of the reforms, the new political situation on Bonaire, St. Eustatius, and Saba could rather be better likened to that of the British Overseas Territories and their relationship with the United Kingdom.
\end{abstract}

Keywords: Bonaire, comparative politics, Dutch Caribbean, non-sovereignty, political reform, post-colonialism, Saba, St. Eustatius, sub-national island jurisdictions

(C) 2015 - Institute of Island Studies, University of Prince Edward Island, Canada

\section{Introduction}

Both in terms of population and territorial size, Saba (population: about 2,000; land area: 13 $\mathrm{km}^{2}$ ) and St. Eustatius, or 'Statia' (population: about 4,000; $21 \mathrm{~km}^{2}$ ) are the smallest nonsovereign jurisdictions in the Caribbean. Together with the Dutch half of the larger eastern Caribbean island of St. Maarten/Saint Martin and the two southern Caribbean islands of Bonaire and Curaçao, these islands formed part of the Netherlands Antilles, an autonomous country within the Kingdom of the Netherlands, until October $2010 .{ }^{1}$ When the dissolution of this post-colonial political structure had become inevitable, during separate referenda held in 2004 and 2005 Bonaire and Saba opted for closer ties with the Netherlands, whereas the population of St. Eustatius expressed a preference for the continuation of the Netherlands Antilles. After protracted and intensive negotiations with The Hague, authorities on the three islands eventually settled for the integration of their islands within the Dutch constitutional and legal framework as special municipalities. ${ }^{2}$ As such, the new political status of these islands marks a definite break with the traditional Dutch colonial practice to keep its Caribbean colonies at a distance; and, after 2010, Dutch metropolitan laws and administrative practices started being implemented on the islands. In consideration of the extremely small size of these

\footnotetext{
${ }^{1}$ The island of Aruba was also part of this country, but in 1986 it became a separate country within the Kingdom.

2 Officially, these islands are 'public bodies' (openbare lichamen) of the Netherlands, but in practice they function as Dutch municipalities. As a group, the islands are often labeled as the 'BES' (Bonaire, St. Eustatius, Saba).
} 


\section{W. P. Veenendaal}

islands, the recent changes have a tremendous societal impact, which inevitably generates tensions and controversies.

The present article seeks to understand the 2010 reform of the Dutch Caribbean municipalities of Bonaire, St. Eustatius, and Saba in the context of the broader academic literature on small non-sovereign island jurisdictions (SNIJs; Baldacchino \& Milne, 2006) in general, and those in the Caribbean in particular. After providing a broad theoretical framework which discusses the various advantages and disadvantages of non-sovereignty in the context of a postcolonial relationship, a concise historical overview of the developments leading up to the dissolution of the Netherlands Antilles is offered. Subsequently, the specific political and societal effects of the 2010 reform of the three Dutch Caribbean municipalities are discussed in more detail, highlighting the perceived advantages and disadvantages of the new political status. In the final analytical section, a broader comparative perspective is employed in order to contrast the 2010 reform of the Dutch Caribbean municipalities with the political and constitutional position of other small, non-sovereign island jurisdictions in the Caribbean. In the conclusion, a case is made for more comparative research on small, non-sovereign island jurisdictions in the Caribbean and beyond.

Before starting the analysis, two caveats need to be made. When discussing the benefits and drawbacks of a non-sovereign political status, this can always be done either from the perspective of the non-sovereign jurisdiction itself, or form the viewpoint of the metropolitan state with which the political relationship is maintained (cf. Rezvani, 2014, p. 20). The present article explicitly adopts the former angle, and therefore primarily analyzes the reforms of 2010 from the perspective of politicians and citizens in the Dutch Caribbean municipalities. Although attention is occasionally paid to the perceptions of the Dutch government in The Hague, this is not the principal focus of the article. After the reforms of 2010, the Kingdom of the Netherlands formally contains four autonomous countries. However, because of the political dominance of the metropolitan Netherlands within the Kingdom, it is not always clear when the Netherlands acts on its own, and when it acts on behalf of the Kingdom government. To avoid unnecessary confusion, in this article the term "The Netherlands" will be used for both instances.

\section{Small non-sovereign island jurisdictions in the academic literature}

In the late $20^{\text {th }}$ century, politicians and academics alike have increasingly come to respect that the self-determination principle in the context of decolonization may also translate into a deliberate popular preference for a non-sovereign, postcolonial status, a choice which needs to be respected (Baldacchino \& Milne, 2006, p. 490; Hintjens, 1997, p. 538; Miles, 2001, p. 46). Whereas the United Kingdom, but also the Netherlands, had until the late 1980s - with varying degrees of success - attempted to bestow independence upon their remaining colonies in the Caribbean and the Pacific, policymakers in these countries increasingly recognized that selfdetermination also entails a former colony's right to remain part of the metropolitan country. In marked contrast to the British and Dutch approaches, France and the United States have sought to preserve their overseas territories in the Caribbean and elsewhere, primarily on the basis of geostrategic arguments (Miles, 2001, p. 48; Ramos \& Rivera, 2001, pp. 1-2). Aside from these metropolitan considerations, in the contemporary non-independent island jurisdictions in the Caribbean and elsewhere, broad majorities of the population oppose political independence, 
and it is perhaps quite telling that the last country to become independent in the region - St. Kitts and Nevis - did so in 1983, more than 30 years ago.

Although over a hundred sub-national island jurisdictions can be identified in the world today (Stuart, 2009), profound differences between these territories exist regarding the extent to which they are autonomous from their respective metropolitan powers (Watts, 2009). In the Caribbean, the French Départements d'Outre Mer (DOMs) have since 1946 been fully constitutionally integrated in the French Republic, whereas The Netherlands in 1954 agreed to grant its islands in the Caribbean the status of an autonomous country within the Kingdom. However, the degree of autonomy apparent in the political and constitutional status of a SNIJ is not always a good indicator of the extent to which a SNIJ factually experiences metropolitan control and oversight. Whereas the United Kingdom, for instance, always refused to politically incorporate its overseas territories, after 1999 London further increased its political control on these jurisdictions (Clegg \& Gold, 2012), thereby arguably further restricting their autonomy. On the other hand, while political incorporation might be interpreted as a restriction of autonomy, as a federal US state Puerto Rico might acquire all the rights and competences pertaining to federal statehood, as a consequence of which its autonomy from Washington may actually increase in comparison to the present Commonwealth arrangement (Duany \& Pantojas-García 2005, p. 23). ${ }^{3}$

Quite a number of motivations and considerations underpinning the preference for nonsovereign status have been listed in the academic literature. In the first place, in economic terms the non-sovereign jurisdictions of the Caribbean clearly outperform their politically independent counterparts, and in this sense the example set by this latter group serves as a rather unappealing scenario (Armstrong \& Read, 2000; Baldacchino \& Milne, 2006, p. 487). From an economic perspective, the continuing relationship with an overseas metropolis might result in a series of benefits for non-sovereign island jurisdictions, ranging from the acquisition of economic aid to membership of free trade arrangements and preferential access to certain world markets. From an international political perspective, the link with the metropolis entails greater territorial security and guaranteed disaster relief, the importance of which, as the example of Montserrat demonstrates, should not be underestimated. ${ }^{4}$ Finally, having a passport of a larger, developed country offers clear opportunities for migration, and also entails access to first-class higher education. Taken together, these factors imply that by opting for a nonsovereign status, small island jurisdictions might indeed be having "the best of both worlds: providing many of the benefits associated with political sovereignty while delegating responsibilities, enjoying security and reaping the material benefits of remaining in association with a larger, and typically richer, albeit often reluctant, patron" (Baldacchino, 2006, p. 49).

Although such a reasoning might indeed explain the strategic choice for nonindependence, the experience of American, British, Dutch, and French overseas territories in the Caribbean also demonstrates that the non-sovereign status is, in many cases, a controversial

\footnotetext{
${ }^{3}$ At present, Puerto Ricans do not pay US federal taxes: one of the main reasons for their under-representation in US political institutions, and their alleged contemporary status as 'second-class citizens' (Pantojas-García, 2005, pp. 168-170). Under the current arrangement, the US administration is ultimately sovereign, because it can unilaterally decide which federal laws apply to Puerto Rico and which ones do not. If Puerto Rico would become a US state, sovereignty would be shared between the federal and state institutions.

${ }^{4}$ In 1995-1997, the Soufrière volcano on Montserrat erupted for the first time since the $19^{\text {th }}$ century, resulting in 19 casualties, the out-migration of two thirds of the population, and the complete devastation of Montserrat. Britain came to the rescue with considerable funds, but at present half of the island's territory remains off limits (the 'exclusion zone'), and the remaining population is strongly dependent on British economic support.
} 


\section{W. P. Veenendaal}

option. In large part, this is due to the apparent trade-off between the two dimensions mentioned by Baldacchino: how much autonomy are non-sovereign island jurisdictions willing to compromise in return for the benefits associated with non-sovereignty? In many nonsovereign Caribbean territories this question is at the heart of heated political discussions, and the ongoing status debates in places like Puerto Rico, Guadeloupe, Bermuda, and Curaçao demonstrates that the meaning and content of the non-sovereign status remain hotly contested issues. ${ }^{5}$ As Carlyle Corbin argues,

It is often projected that the NSGTs [non self-governing territories] are content with their respective political dependency arrangements, and that they exercise a full measure of self-governance. However, this is not consistent with the objective reality in the territories where varying degrees of dissatisfaction with the democratic deficiencies of the prevailing political arrangements have been expressed by elected leaders with varying degrees of support from civil society (Corbin, 2012, p. 165).

According to this alternative perspective, instead of procuring "the best of both worlds", nonsovereign jurisdictions might be seen as locked in a postcolonial impasse.

The existing dissatisfaction with the non-sovereign political status in many SNIJs can be related to the perceived disadvantages of this status, which to varying degrees counterbalance the aforementioned advantages. In the first place, as the term 'non-sovereign' obviously implies, all SNIJs experience limited political autonomy in at least one or more policy areas. Although the extent to which metropolitan powers can unilaterally implement laws and policies in the overseas territories differs per case, all non-sovereign territories experience this 'external' political interference. Secondly, in many cases (but, for instance, not in the French overseas territories), the populations of the SNIJs are not equally represented in the political institutions of the metropolis, which further decreases the legitimacy of metropolitan interference in local politics. Finally, from a more psycho-social perspective, most prominently in postcolonial settings, non-sovereign status results in conflicted feelings of identity. On the one hand, independence is often regarded as a prerequisite for nation-building and political emancipation; yet, on the other hand, for chiefly pragmatic reasons, the link with the metropolis (or former colonial power) is retained. This predicament creates a political tension in many SNIJs, and constitutes the basis for a continuing debate about non-sovereign political status.

The indeterminacy and contentious nature of the ongoing status debates in many nonsovereign territories is accompanied by many popular votes on political reforms that have occurred in recent years and decades. Since 2000, multiple referenda on political status have been held in Puerto Rico and in all of the French and Dutch overseas territories in the Caribbean, which means that only the British overseas territories seem to be excluded from this trend. However, on average, these islands are economically arguably the most successful nonsovereign jurisdictions in the Caribbean, and an extensive reform process of the British overseas territories has been underway since the late 1990s (Clegg \& Gold, 2012).

In sum, the continuing (debates on) reforms demonstrate not only that the nonsovereign status is in itself often perceived as a rather controversial political arrangement, but also that it can be hard to find a way to structure this relationship in an effective and

\footnotetext{
${ }^{5}$ The same is true of non-sovereign territories elsewhere, such as Greenland and New Caledonia.
} 
satisfactory manner. As the following section demonstrates, this conclusion also pertains to the Dutch overseas territories in the Caribbean.

\section{Background: the dissolution of the Netherlands Antilles}

On 10 October 2010, the country of the Netherlands Antilles was officially dismantled with a flag-lowering ceremony in Willemstad, Curaçao. In the preceding decade, intense and protracted negotiations between the Dutch government in The Hague and the five islands constituting the Netherlands Antilles had resulted in the agreement that the two largest islands of the country, Curaçao and St. Maarten, would become separate, individual countries within the Kingdom, a status which the island of Aruba had already obtained in 1986. The three smaller islands of Bonaire, Saba, and St. Eustatius, on the other hand, were to become public bodies (openbare lichamen) of the metropolitan Netherlands, and would in this sense be constitutionally integrated within the Dutch legal and political system. The choice of these islands for closer, direct links with the metropolitan Netherlands followed the outcomes of separate status referenda held on each of the islands in 2004 and 2005, during which a majority of voters on Bonaire and Saba opted for direct relations with the Netherlands, whereas over 75 per cent of voters on St. Eustatius preferred to retain the status quo. Since St. Eustatius was the only island favoring this alternative, the local island council subsequently opted for the trajectory Bonaire and Saba had already settled for (Hillebrink, 2008, p. 352; Oostindie \& Klinkers, 2012, p. 34).

The dissolution of the Netherlands Antilles constitutes a new step in the ongoing and often problematic trajectory of Dutch Caribbean decolonization (cf. De Jong \& Van der Veer, 2012; Giacalone, 2001; Oostindie \& Klinkers, 2001; Sedoc-Dahlberg, 1990b). Indonesia (the Dutch East Indies) gained independence following a 4-year period of both protracted negotiations as well as a guerilla war of independence between 1945 and 1949. Then, in 1975, sovereignty was haphazardly yet adamantly bestowed upon Suriname, resulting in a dramatic exodus as part of which one third of the population of this country migrated to the Netherlands, apparently having no confidence in the viability of the new state (Hoefte, 1996, pp. 36-38; Oostindie, 2006, p. 128). As a consequence, from the start, Suriname was bereft of a large part of its intellectual and economic potential. In subsequent years, the country remained dependent on Dutch financial aid and experienced an authoritarian military regime between 1980 and 1987 (Sedoc-Dahlberg, 1990a; Thorndike, 1990). After 1975, the six Dutch Caribbean islands, since 1954 constitutionally united in the country of the Netherlands Antilles, remained as the sole remnants of the Dutch empire.

The political and constitutional relationship between the metropolitan Netherlands and the Caribbean overseas territories is regulated by the Charter for the Kingdom of the Netherlands (Statuut voor het Koninkrijk der Nederlanden), which was ratified in 1954. Although the membership of the Kingdom and the degree of autonomy of the various islands it encompasses have changed, the provisions and regulations of the Charter have essentially remained intact, and are therefore still operative today. The Charter basically entrenches the autonomy of the various countries within the Kingdom, and stipulates that - with only few exceptions (such as foreign policy, defence, and matters related to nationality) - the countries are entitled to govern themselves. Furthermore, since the Charter stipulates that the countries are politically equivalent, the provisions of the Charter can only be modified when all partners agree with the proposed changes. On the other hand, and to a certain degree at odds with the 


\section{W. P. Veenendaal}

aforementioned terms, article 43 of the Charter states that the safeguarding of human rights, the rule of law, and good governance is a responsibility of the Kingdom as a whole (Charter of the Kingdom of the Netherlands, 1954).

In contrast to Indonesia and Suriname, independence has never been regarded as a desirable goal by the populations of the Dutch Caribbean islands (Oostindie \& Verton, 1998). Many local politicians theoretically favour independence but do not consider this to be a realistic goal in the near future, even though especially Curaçaoan politicians nowadays occasionally express secessionist sentiments. Yet, while the islands have steadfastly rejected independence, they have also adamantly opposed the postcolonial political construction of the Netherlands Antilles in which they were united. Territorially, the Netherlands Antilles were composed of the three Anglophone Windward Islands of Saba, St. Eustatius, and St. Maarten, and the three Papiamentu-speaking Leeward Islands of Aruba, Bonaire, and Curaçao, separated by 900 kilometers of sea. Whereas the federal political union of these islands enabled the Netherlands to deal with all of them at once through the Antilles' central administration in Willemstad, geographical, historical and cultural differences between the islands prevented the emergence of an Antillean nation or sense of common identity.

In fact, the relations between the different islands were characterized by strong insular antagonisms, resulting in secessionist tendencies. Longstanding Aruban grievances against the perceived dominance of Curaçao resulted in the granting of a status aparte to this island in 1986, when it became a separate country within the Kingdom of the Netherlands (Lampe, 2001; Oostindie, 2006, p. 129). The Aruban departure meant that the supremacy of Curaçao within the Netherlands Antilles became even more profound, leading St. Maarten to express a preference for a separate country status as well. Curaçaoan politicians, on the other hand, increasingly expressed a wish to be released from the financial burden allegedly posed by the smaller islands (Hoefte, 1996, p. 43; Oostindie, 2006, p. 131). In the end, the dissolution of the Netherlands Antilles had therefore become politically inevitable, or at least was increasingly perceived as such on the islands and by the Dutch political authorities in The Hague.

In addition to the separatist inclinations on the islands, the failure of the Netherlands Antilles' administration to curb the growing socio-economic and drugs- and crime-related problems had gradually decreased its legitimacy in the eyes of the Dutch politicians (De Jong, 2009, pp. 28-33; Nauta, 2011, pp. 13-14). The administrative layer of the country gradually came to be regarded as inefficient and exorbitantly costly, and The Hague increasingly dealt with the separate political institutions of each island on a bilateral basis. Furthermore, problems related to corruption and maladministration emerged on the islands during the 1990s. Yet, whereas the Charter of the Kingdom legally entrenches the autonomy of the Netherlands Antilles - thus largely preventing Dutch political intervention - the Charter simultaneously identifies the safeguarding of human rights and good governance as a responsibility of the Kingdom as a whole. Mounting Dutch frustration with this equivocal state of affairs and enduring financial and economic problems on the islands resulted in a yearning for more political tools to intervene in the case of perceived problems in the sphere of good governance. Taken together, these factors explain the Dutch willingness to start the status negotiations which the islands had asked for.

The 2010 reforms were met with high hopes on both sides of the Atlantic. St. Maarten and Curaçao finally obtained the status aparte they desired, and St. Maarten was finally released from the political dominance of Curaçao, resented for decades on end (Badejo, 1990). The smaller islands of Saba and Bonaire had finally acquired the long-preferred direct political 
relationship with the Netherlands, and these islands primarily anticipated rising standards of living and better education and health services as a consequence. Whereas the population of St. Eustatius initially preferred the continuation of the Netherlands Antilles, on this island the benefits of the direct political link with the Netherlands were recognized as well. For all the islands, the Dutch willingness to write off $€ 1.7$ billion out of around $€ 2$ billion of public debt which the Netherlands Antilles had accrued over the decades was a crucial incentive. The Hague, on the other hand, negotiated increased supervision over the finances and public budgets of Curaçao and St. Maarten, and expected that the removal of the malfunctioning administration of the Netherlands Antilles would secure greater administrative effectiveness and integrity. For all players involved, the 2010 reforms were thus lauded as a fresh start of the trans-Atlantic political relationship, even though the political opposition (especially on Curaçao and Bonaire) criticized the new political status, arguing that too much autonomy had allegedly been given up during negotiations (Oostindie \& Klinkers, 2012, pp. 258-263).

\section{The new political status of the Dutch Caribbean municipalities}

As the smallest members of the Netherlands Antilles, Bonaire, St. Eustatius, and Saba (BES) have always been politically and economically subordinate to the larger islands in this federation, and in particular to Curaçao, where the central administration of the country was located. In this sense, these islands could at least historically be regarded as 'colonies of a colony'; yet, in contrast to Aruba and St. Maarten, they did not have the size and accompanying political and economic resources to truly challenge the dominance of Curaçao. Within the Netherlands Antilles, Bonaire and the three Windward Islands always supported Curaçao and the federal government, since they were completely dependent on financial and economic funds from these larger political actors (Klomp, 1983, p. 113). St. Maarten's rapid economic and demographic growth over the 1970s and 1980s strongly diminished this island's dependence on the federal government, as a consequence of which it acquired the tools and resources to politically challenge Curaçao (Badejo, 1990, pp. 128-129). For St. Eustatius and Saba on the other hand, St. Maarten's rise arguably had an adverse effect, as St. Maarten now came to dominate the Windward Island unit in which the three islands had always been united, resulting in the breakup of this construction in 1984.

Having always been dependent on other islands, the BES-islands' yearning for direct relations with the Netherlands was quite comprehensible, and by itself this aspiration seemed to be shared by basically all segments of these islands' societies. However, the extent to which these direct relations should be accompanied by greater Dutch administrative involvement and control has been a strongly divisive issue, and the main opposition party on Bonaire at the time (the Partido Demokrátiko Boneriano) for example constantly criticized the newly negotiated status of the island. As described above, the balance between the disadvantages of reduced autonomy and the advantages inherent in the metropolitan link strongly influences the status debate in most sub-national island jurisdictions, and the Dutch Caribbean municipalities are certainly no exception in this regard. The discussion on St. Eustatius is particularly interesting because the population of this island never officially sanctioned the status which the island now acquired, and it is therefore to a certain extent questionable whether the UN-established right to self-determination has been fully respected here (Duijf \& Soons, 2011, pp. 34-35; Hillebrink, 2008, p. 352). 


\section{W. P. Veenendaal}

Since 10 October 2010, Bonaire, St. Eustatius, and Saba are special municipalities of the Netherlands, and Dutch legal and administrative regulations are now gradually introduced and implemented on the islands. In contrast to regular Dutch municipalities, political power on the three islands is shared between the locally elected island councils, headed by a Gezaghebber (mayor) appointed by the Dutch Crown, and the central Dutch government, which is represented on the islands by the Rijksdienst Caribisch Nederland (National Office for the Caribbean Netherlands), headed by a Rijksvertegenwoordiger (Lieutenant-Governor) for the three islands together. As a result, 'local government' on the islands now by definition involves both domestic and metropolitan institutions and actors, but the inherent inequalities in political power, financial capacities, and administrative resources entail that the relations between these institutions are characterized by huge asymmetries. Apart from this predicament, the societal impact of the influx of many Dutch bureaucrats and citizens working for the Rijksdienst should not be underestimated, especially on the two smallest islands, which only have 2,000 and 4,000 inhabitants respectively.

Since the political reforms have occurred only very recently, and because in-depth research on these extremely small islands is lacking in general, no definitive conclusions about the success and local evaluation of the new status can be drawn yet. However, all the available evidence suggests that dissatisfaction is the prevailing present-day sentiment on the islands (Oostindie \& Klinkers, 2012, pp. 262-265), and there are a number of potential reasons for this. In the first place, whereas the islanders anticipated rising standards of living and improved services, they perhaps did not envisage having to implement liberal Dutch laws on socio-moral issues like euthanasia, abortion, and gay marriage, which to a large degree are not supported by the local populations and therefore lack popular legitimacy. Under the new rules, the Dutch government can decide which Dutch laws should be implemented on the islands and which ones not, and the population of the islands appears to perceive that whereas laws on moral issues have to be rapidly effected, there is no corresponding rush on the part of The Hague to apply regulations relating to social welfare benefits and salaries (Oostindie \& Klinkers, 2012, p. 264). In this regard, the Dutch government stipulated that the island populations are not entitled to provisions similar to the Netherlands, but would have to accept "reasonable levels" (Scheepmaker, 2009, p. 7).

A second potential reason for resistance towards the new arrangement on the islands, is the perceived absence of mutual interest between the three islands. This is not the case for Saba and St. Eustatius, which maintain a longstanding and friendly historical relationship (Guadeloupe, 2009, p. 49), but it certainly does apply to the relations between these two islands and Bonaire, which is located 900 kilometers away, and in which Papiamentu instead of English is spoken. Despite the fact that all these islands resented their respective dependence on Curaçao within the Netherlands Antilles, this never resulted in any form of solidarity between them. As Klomp describes,

[The Windward Islands] were beyond Bonaire's horizon in thought as well as fact. The fact that the Windwards were also poor and dependent on the contributions of the national government did not do much to arouse Bonairean interest (Klomp, 1990, p. $110)$.

As the largest of the three Dutch Caribbean municipalities, since 2010 the headquarters of the Rijksdienst are located on Bonaire, and regardless of whether it is accurate, this might instantly 
evoke a sensation among Sabans and Statians that they have once more become dependent on some faraway, larger island (Oostindie \& Klinkers, 2012, p. 264).

As in other small island nations in the Caribbean (Farrugia, 1993; Richards, 1982; Sutton, 2007; Veenendaal, 2013), local politics on the BES islands is traditionally strongly personalized and polarized, and the small-scale environment has resulted in very close relations between citizens and politicians (Klomp, 1983; Oostindie \& Sutton, 2006; Van den Bor, 1979; Verton, 1973). In this context, the status issue rapidly becomes an important bone of contention between strongly antagonistic political parties. Moreover, in the Dutch Caribbean municipalities, the political opposition has been keen to instantly reject the political status that was attained by the governing party during the negotiations leading up to 2010. In this sense, the small scale of not only these special municipalities, but also many sub-national island jurisdictions in the Caribbean and Pacific, undercuts the attainment of consensus among the population about a preferred political status. On Bonaire, one of the two main political parties supported the new status, while the other one vocally opposed it, and after gaining office immediately promised to organize a referendum and reopen the status negotiations. As in other Caribbean SNIJs, therefore, the lack of popular consensus about the desired political status, which is to a large extent fueled by the adversarial politics between political parties, also prevents the attainment of an enduring political settlement that is endorsed by a wide majority of the population.

A first analysis of the local attitudes with respect to the functioning of the Rijksdienst indicated that whereas Bonairean, Saban, and Statian people are generally negative about issues like taxation, purchasing power, and wages, which can be more broadly related to the perceived rising costs of living, they are generally positive about developments regarding education, health care, immigration services, and the police (Curconsult, 2012). When asked about their expectations for the future, $41 \%$ of the population of the Dutch Caribbean municipalities expected that their island will be better off in the future, but in this regard Sabans and Statians were quite a bit more optimistic than Bonaireans. Despite the ostensibly ambivalent judgments about the newly attained status, according to Oostindie and Klinkers local politicians and citizens did anticipate a period of political and administrative tranquility after years of intensive negotiations (Oostindie \& Klinkers, 2012, p. 264). This however does not mean that the debate about the political status is now laid to rest on the islands. St. Eustatius held yet another status referendum on December $17^{\text {th }} 2014$, during which a majority of voters cast a ballot in favour of autonomy within the Kingdom. Because voter turnout however remained below the threshold of the $60 \%$ required for the result to be binding, this referendum did not have any direct political consequences (Saba News, 2014). On Bonaire, demonstrations for a new referendum are currently being organized as well.

\section{The comparative Caribbean context}

As mentioned before, in contrast to the American and French approaches, Dutch decolonization policy in the Caribbean has for long been characterized by disengagement. From the early 1970s to the early 1990s, The Hague actively tried to bestow independence on its Caribbean colonies, and only when Dutch politicians realized that this goal could not be realized anytime soon, did their political pressure and influence on the Caribbean islands increase. To some extent, these Dutch decolonization policies can be compared to those of the United Kingdom, but the difference is that a wide majority of British Caribbean colonies did 


\section{W. P. Veenendaal}

become independent during the 1960s, 1970s, and 1980s, with only the smallest overseas territories remaining linked to the United Kingdom (Connell, 2001, p. 115; Ramos, 2001, p. xiii). Even though many American and French Caribbean territories, such as Puerto Rico, Guadeloupe, Martinique, and French Guyana are both in terms of territory and population much larger than most of the now-independent, former British colonies in the Caribbean, after the Second World War none of the French and American overseas territories in the West Indies have become independent.

When observed as a reform towards political integration with the metropolis, the new status of the BES islands can be compared to the French postwar policy of départementalisation. Already in 1946, France completely integrated its overseas territories in the French Republic as Départements d'Outre Mer (or DOMs; Hintjens, 1997, p. 536; Mrgudovic, 2012, pp. 85-86). As such, the inhabitants of these DOMs are entitled to standards of living similar to those of metropolitan France, and since the establishment of the DOM status, socio-economic conditions have indeed improved enormously. However, as Justin Daniel underscores, not only has this policy been extremely expensive, but " $t \mathrm{t}] \mathrm{he}$ welfare state has paradoxically served as an impediment to economic development in the French Antilles.... It is correct to speak about a global strategy of development through dependency" (Daniel, 2001, pp. 63-64; cf. Oostindie \& Klinkers, 2003, pp. 36-37). The guaranteed flow of money from Paris and, increasingly, Brussels, has allowed local political elites to establish pervasive patron-client networks, and to focus on the short-term rather than the long-term economic interests of the respective DOMs. Since the constitutional revision of 2003 the French overseas territories of St. Martin and St. Barthélemy, which were formerly administered from Guadeloupe, have become separate Collectivités d'Outre Mer (COMs; Mrgudovic, 2012, pp. 88-92). ${ }^{6}$ As such, these jurisdictions have acquired more decision-making power in a number of fields, but French metropolitan laws are still directly applicable here. In the beginning of 2009, riots and strikes erupted on Guadeloupe and Martinique as a reaction to rising costs of living, once more highlighting the continuing popular dissatisfaction with the present-day situation on the islands.

The political integration of the Dutch Caribbean municipalities with the metropolitan Netherlands stands in contrast with developments in the broader Caribbean region, where "the reforms currently in progress are toward greater autonomy for the various territories" (Sutton, 2009, p. xl). Now that Bonaire, St. Eustatius and Saba are, however, constitutionally integrated into the metropolitan Netherlands, it can be questioned to what extent a 'French' scenario can be expected for these islands. As in the French DOMs, public administration on the Dutch Caribbean municipalities is now to a significant extent executed by metropolitan civil servants; and, analogous to the situation in the DOMs, this might lead to frustration among the local middle classes on the islands (Oostindie \& Klinkers, 2003, p. 36). In the end, however, the population of the DOMs has always continued to support the political assimilation with France. In the early 2000s, attempts from the side of Paris to promote status change in order to stimulate good governance and economic development in the DOMs were rejected by the populations of Guadeloupe and Martinique (Daniel, 2009, pp. 71-74; Mrgudovic, 2012, p. 92). ${ }^{7}$

\footnotetext{
${ }^{6}$ The French SNIJ of Mayotte (in the Indian Ocean) became a collectivité départementale in 2001, and after a referendum held in 2009, it acquired the status of département d'outre mer.

${ }^{7}$ During referenda held on 7 December 2003, 51\% of Martinican and 73\% of Guadeloupean voters rejected the proposal to consider a single territorial collectivity for these islands.
} 
An obvious difference between the Dutch Caribbean municipalities and the DOMs is of course their respective population and territorial size, and the ensuing financial significance and potential burden they pose on the metropolis. In this regard, the new political situation on Bonaire, St. Eustatius, and Saba could perhaps better be compared with the smaller - and economically more successful - COMs of St. Martin and St. Barthélemy. However, perhaps the most important dissimilarity between these French and Dutch islands is historical in nature: whereas the Dutch had until recently never been strongly present on their Caribbean islands, the French have traditionally always aimed to disseminate the metropolitan language, culture, and traditions to their overseas territories. The strong Dutch presence in the Caribbean municipalities since 2010 constitutes a substantial break with the (recent) past, and might therefore instantly evoke sensations of 'recolonization' or annexation. In the French DOMs and $\mathrm{COMs}$, on the other hand, the trend appears to be in the other direction, and since the early 2000s these overseas territories have arguably gained more responsibility in their relationship with the metropolis (Mrgudovic, 2012, pp. 91-92).

Instead of comparing the Dutch Caribbean municipalities to the DOMs, in terms of both size and history the parallels with the British Overseas Territories (BOTs), and the direction of the political reforms that have occurred in the relationship between the United Kingdom and its BOTs since the late 1990s, are perhaps more palpable. Although the BOTs are not politically integrated into the United Kingdom as special municipalities, since the 1999-reforms the British authorities do have a larger influence on governance and policy-making in their overseas territories (Clegg, 2009, p. 3; Clegg \& Gold, 2012, pp. 26-27; 36). This is primarily the case because the Governor of the BOTs, who is appointed by the British government on behalf of the Crown, exerts a major influence on political appointments, law-making, and public administration; on paper the power of the Governor seems virtually unlimited (Nauta, 2011, pp. 106-112). Furthermore, the British parliament can at any time adopt and implement binding laws for the BOTs, and it has recurrently happened that laws for the specific overseas territories were devised by the House of Commons. Even though no British civil servants are working in the BOTs on a structural basis, and the territories are not politically integrated into the metropolitan United Kingdom, officially Westminster's political instruments to intervene in the case of perceived mismanagement seem to be quite comparable to the new situation in the Dutch Caribbean municipalities.

And yet, "the more pro-active attitude of the UK government created new tensions that highlighted the sensitivities of the territories when their autonomy was threatened" (Clegg, 2009 , p. 12). In particular, and strongly analogous to the post-2010 context in the Dutch Caribbean municipalities, the UK's attempts to decriminalize homosexuality met with strong resistance from local politicians and citizens. Although the citizens of the BOTs acquired British citizenship and, by extension, the right of abode in the United Kingdom, the new British policy also entails greater metropolitan control on human rights, offshore finances, and good governance. Regarding this latter issue, the 2009 corruption scandals in the Turks and Caicos Islands underscored that problems related to maladministration continue to emerge, and that the British government is actually quite reluctant to use its powers and prerogatives to enforce good governance on the BOTs (Clegg \& Gold, 2012, p. 36). Although the position of the Governor may look omnipotent on paper, in practice there are significant constraints to his/her action and authority. It is perhaps still too early to say whether a similar conclusion can be drawn for the Dutch Caribbean municipalities, but in 2012 a major corruption scandal involving several high-ranking local politicians surfaced on Bonaire, thereby instantly testing 


\section{W. P. Veenendaal}

the readiness of the Dutch authorities to intervene in local politics. Although various Dutch political parties urged the government to take action, The Hague was hesitant to interfere in local Bonairean politics, and insisted on awaiting the results of the lawsuit against the Bonairean politicians. ${ }^{8}$ In conclusion, whereas recent reforms of both the BOTs and the Dutch Caribbean municipalities officially strengthened the metropoles' tools to take political action in their respective SNIJs, for practical reasons both the Netherlands and the United Kingdom remain essentially reluctant to do so. ${ }^{9}$

Problems related to good governance and respect for human rights arise in all of the SNIJs in the Caribbean, and these issues obviously influence, confound, and encumber the status debates in these territories. Many of the problems related to personalistic politics, patronclient relationships, the excessive dominance of government, and the victimization of political opponents can be related to the smallness of these jurisdictions (Oostindie \& Sutton, 2006; Veenendaal, 2014), and can also be observed in small, sovereign Caribbean island states like St. Kitts and Nevis (Veenendaal, 2013b). In relation to the issue of political status, these problems in governance not only result in strongly partisan, polarized, and antagonistic discussions that obstruct the attainment of consensus about the preferred political status among the population, but also may create disparities between the aims of citizens and their political representatives. Since the patron-client linkage usually entails casting a vote on the basis of particularistic instead of substantive political incentives, widespread patron-client linkages have been found to distort the substantive representation of citizens' interests (Kitschelt, 2000). If this line of reasoning indeed applies to the SNIJs, the opinions of politicians in these territories regarding the preferred political status may not correspond to those of citizens, thereby further confounding the negotiations and attainment of a satisfactory political arrangement with the metropolis.

Whereas the opposition to independence by large population segments did not prevent many small countries such as Suriname, Seychelles, and the Anglophone Eastern Caribbean island nations from becoming sovereign states over the 1960s, 1970s and early 1980s, at present in many SNIJs the standoff between supporters and opponents of different statuses leads to a stagnation of political reform. Perhaps the most typical example in this regard is the Commonwealth of Puerto Rico, where the population for decades has been almost evenly split over the alternatives of an enhanced Commonwealth status versus federal US statehood (Rivera, 2009). Although the populations of Bonaire and Curaçao were by no means in agreement about the desired political status, the reforms on these islands were implemented nonetheless, and when the Bonairean opposition came to power it immediately organized a referendum, which was eventually held on 17 December 2010, less than 3 months after the new status had been obtained (Oostindie \& Klinkers, 2012, p. 59). Although the turnout figure at this popular vote was only $35 \%$, and the results were therefore declared invalid, almost $87 \%$ of voters rejected the new political status, thereby once more exposing the divide among the Bonairean population on this issue.

\footnotetext{
${ }^{8}$ In April 2014, the most important suspects were acquitted by the court of the Netherlands Antilles in Curaçao.

${ }^{9}$ Before 2010, the Dutch government had decided to intervene on the islands on several occasions. However, since 2010, for the Caribbean municipalities this decision is no longer a matter of the 'Kingdom' as a whole, but can happen on the instigation of the Netherlands alone. For Curaçao and St. Maarten, since 2010 no special permission or request from the administration of the Netherlands Antilles is necessary.
} 


\section{Conclusion}

With a new status referendum held in St. Eustatius, and another one potentially upcoming in Bonaire, the debate about the political status of the Dutch Caribbean municipalities has not withered after 10/10/10. The islands are released from the dependency on Curaçao and the administration of the Netherlands Antilles; they have received strong Dutch political interference and presence, but also financial and economic support, in return. It is still too early to say whether the establishment of Dutch institutions and the provision of Dutch services to the islands will result in higher standards of living, and thus perhaps a more positive attitude towards the new municipal status. But even if this were to be realized, it can be questioned to what extent the island populations have now obtained a satisfactory balance between the benefits of the metropolitan link and the drawbacks of diminished autonomy. At various times, the Dutch authorities in The Hague have made clear that the only acceptable alternative to the present status would be for the islands to become completely independent (Oostindie \& Klinkers, 2012, p. 248). In 2015, five years after the dissolution of the Netherlands Antilles, the Dutch government will conduct a first official evaluation of the constitutional reforms and the newly acquired political status of the Caribbean municipalities.

As the present article has discussed, the 2010 reform of the Dutch Caribbean municipalities in some ways deviates from, and in some respects mirrors, developments in other Caribbean SNIJs. Whereas the option of integration with the metropolis in itself can be compared to the French policy vis-à-vis the DOMs and COMs, in terms of the pattern of reforms the increased Dutch political control on Bonaire, St. Eustatius, and Saba can in many ways be likened to the post-1999 relationship between the UK and its overseas territories. Yet, in spite of these similarities, the Dutch government by and large appears to neglect the experience of comparable cases in the Caribbean region. A recent report on (the lack of) good governance in St. Maarten strongly encouraged the Dutch government to pay closer attention to the regional Caribbean context in assessing and analyzing the problems on the island, noting that other islands in the region are struggling with similar political integrity problems (Commissie Integer Openbaar Bestuur, 2014).

A similar call can be made for scholars of non-sovereign island jurisdictions. SNIJs are, in a broader sense, under-researched in comparative political science (Veenendaal \& Corbett, 2014); and available publications are often strongly case-oriented and therefore largely idiosyncratic in nature. More systematic comparative research on the various ways in which different SNIJs and their metropolitan governments deal with the dilemmas inherent to the status of non-sovereignty can only lead to a better understanding of the incentives and motivations of both sides of the mainland-island link. Such comparisons would also allow us to better explain, and perhaps even predict, consequences of specific non-sovereign arrangements that other metropoles and overseas territories may have already experimented with.

\section{Acknowledgements}

I would like to thank three anonymous reviewers for helpful comments and suggestions. I also thank Gert Oostindie for comments on an earlier draft. The usual disclaimers apply. 


\section{References}

Armstrong, H.W., \& Read, R. (2000). Comparing the economic performance of dependent territories and sovereign microstates. Economic Development and Cultural Change, 48(2), 285-306.

Badejo, F. (1990). Sint Maarten: the Dutch half in future perspective. In B. Sedoc-Dahlberg (Ed.), The Dutch Caribbean: Prospects for democracy (pp. 119-150). New York: Gordon and Breach.

Baldacchino, G. (2006). Managing the hinterland beyond: two ideal-type strategies of economic development for small island territories. Asia Pacific Viewpoint, 47(1), 45-60.

Baldacchino, G., \& Milne, D. (2006). Exploring sub-national island jurisdictions: an editorial introduction. The Round Table, 95(386), 487-502.

Charter of the Kingdom of the Netherlands. (1954). Retrieved from http://wetten.overheid.nl/BWBR0002154/

Clegg, P. (2009). Governing the UK Caribbean overseas territories: A two-way perspective. In P. Clegg \& E. Pantojas-García (Eds.), Governance in the non-independent Caribbean (pp. 3-23). Kingston, Jamaica: Ian Randle Publishers.

Clegg, P., \& Gold, P. (2012). The UK overseas territories: a decade of progress and prosperity? In P. Clegg \& D. Killingray (Eds.), The non-independent territories of the Caribbean and Pacific: Continuity or change? (pp. 19-39). London: Institute of Commonwealth Studies.

Commissie Integer Openbaar Bestuur. (2014). Doing the right things right. Philipsburg, St. Maarten.

Connell, J. (2001). Eternal empire: Britain's Caribbean colonies in the global arena. In A. G. Ramos \& A. I. Rivera (Eds.), Islands at the crossroads. Politics in the non-independent Caribbean (pp. 115-135). Kingston, Jamaica: Ian Randle Publishers.

Corbin, C. (2012). Self-governance deficits in Caribbean non-independent countries. In P. Clegg \& D. Killingray (Eds.), The non-independent territories of the Caribbean and Pacific: Continuity or change? (pp. 163-193). London: Institute of Commonwealth Studies.

Curconsult. (2012). "Samen verder bouwen": Eenmeting belevingsonderzoek Caribisch Nederland. Willemstad, Curaçao.

Daniel, J. (2001). The construction of dependency: Economy and politics in the French Antilles. In A.G. Ramos \& A.I. Rivera (Eds.), Islands at the crossroads: Politics in the nonindependent Caribbean (pp. 61-79). Kingston, Jamaica: Ian Randle Publishers.

Daniel, J. (2009). Recent developments in the French Antilles. In P. Clegg \& E. Pantojas-García (Eds.), Governance in the non-independent Caribbean (pp. 61-83). Kingston, Jamaica: Ian Randle Publishers.

De Jong, L. (2009). The implosion of the Netherlands Antilles. In P. Clegg \& E. Pantojas-García (Eds.), Governance in the non-independent Caribbean (pp. 24-44). Kingston, Jamaica: Ian Randle Publishers.

De Jong, L., \& Van der Veer, R. (2012). Reformation of the Kingdom of the Netherlands. In P. Clegg \& D. Killingray (Eds.), The non-independent territories of the Caribbean and Pacific: Continuity or change? (pp. 61-84). London: Institute of Commonwealth Studies.

Duany, J., \& Pantojas-García, E. (2005). Fifty years of Commonwealth: the contradictions of free associated statehood in Puerto Rico. In L. de Jong \& D. Kruijt (Eds.), Extended statehood in the Caribbean (pp. 21-57). Amsterdam: Rozenberg Publishers. 
Duijf, C., \& Soons, F. (2011). Zelfbeschikkingsrecht Bonairianen, Statianen en Sabanen. Openbaar Bestuur, October, 31-36.

Farrugia, C.J. (1993). The special working environment of senior administrators in small states. World Development, 21(2), 221-226.

Giacalone, R. (2001). The political status of Curaçao at the end of the twentieth century. In A. G. Ramos \& A. I. Rivera (Eds.), Islands at the crossroads: Politics in the non-independent Caribbean (pp. 95-105). Kingston, Jamaica: Ian Randle Publishers.

Guadeloupe, F. (2009). De verdrijving van Hulanda: De Sabanen en hun toekomst als BESeilanders. Justitiële Verkenningen, 35(5), 48-62.

Hillebrink, S. (2008). The right to self-determination and post-colonial governance: The case of the Netherlands Antilles and Aruba. The Hague: T.M.C. Asser Press.

Hintjens, H. (1997). Governance options in Europe's Caribbean Dependencies: The end of independence. The Round Table, 344, 533-547.

Hoefte, R. (1996). Thrust together: The Netherlands relationship with its Caribbean partners. Journal of Interamerican Studies and World Affairs, 38(4), 35-54.

Kitschelt, H. (2000). Linkages between citizens and politicians in democratic polities. Comparative Political Studies, 33(6/7), 845-879.

Klomp, A. (1983). Politiek op Bonaire. Utrecht: Instituut voor Culturele Antropologie.

Klomp, A. (1990). Bonaire within the Dutch Antilles. In B. Sedoc-Dahlberg (Ed.), The Dutch Caribbean: Prospects for democracy (pp. 103-117). New York: Gordon and Breach.

Lampe, A. (2001). The recolonization of Aruba. In A.G. Ramos \& A.I. Rivera (Eds.), Islands at the crossroads: Politics in the non-independent Caribbean (pp. 106-114). Kingston, Jamaica: Ian Randle Publishers.

Miles, W. F. S. (2001). Fifty years of assimilation: assessing France's experience of Caribbean decolonization through administrative reform. In A.G. Ramos \& A.I. Rivera (Eds.), Islands at the crossroads: Politics in the non-independent Caribbean (pp. 45-60). Kingston, Jamaica: Ian Randle Publishers.

Mrgudovic, N. (2012). The French overseas territories in transition. In P. Clegg \& D. Killingray (Eds.), The non-independent territories of the Caribbean and Pacific: Continuity or change? (pp. 85-103). London: Institute of Commonwealth Studies.

Nauta, O. (2011). Good governance in 'the West'. Universiteit Utrecht, Utrecht.

Oostindie, G. (2006). Dependence and autonomy in sub-national island jurisdictions: The case of the Kingdom of the Netherlands. The Round Table, 95(386), 609-626.

Oostindie, G., \& Klinkers, I. (2001). Knellende koninkrijksbanden: Het Nederlandse decolonisatiebeleid in de Caraïben, 1940-2000. Amsterdam: Amsterdam University Press.

Oostindie, G., \& Klinkers, I. (2003). Decolonizing the Caribbean: Dutch policies in a comparative perspective. Amsterdam: Amsterdam University Press.

Oostindie, G., \& Klinkers, I. (2012). Gedeeld Koninkrijk: De ontmanteling van de Nederlandse Antillen en de vernieuwing van de trans-Atlantische relaties. Amsterdam: Amsterdam University Press.

Oostindie, G., \& Sutton, P. (2006). Small scale and quality of governance. Leiden: KITLV.

Oostindie, G., \& Verton, P. (1998). Ki sorto di Reino / What sort of Kingdom? Visies en verwachtingen van Antillianen en Arubanen omtrent het Koninkrijk. Leiden: KITLV.

Pantojas-García, E. (2005). The Puerto Rican paradox: colonialism revisited. The Latin American Research Review, 40(3), 163-176. 
Ramos, A. G. (2001). Caribbean territories at the crossroads. In A. G. Ramos \& A. I. Rivera (Eds.), Islands at the crossroads: Politics in the non-independent Caribbean (xii-xxi). Kingston, Jamaica: Ian Randle Publishers.

Ramos, A. G., \& Rivera, A. I. (2001). Puerto Rico: regional transformations and political change. In A. G. Ramos \& A. I. Rivera (Eds.), Islands at the crossroads: Politics in the non-independent Caribbean (pp. 1-27). Kingston, Jamaica: Ian Randle Publishers.

Rezvani, D. (2014). Surpassing the sovereign state. Oxford: Oxford University Press.

Richards, J. (1982). Politics in small independent communities: conflict or consensus? Journal of Commonwealth and Comparative Politics, 20(2), 155-171.

Rivera, A. I. (2009). US non-incorporated territories in the Caribbean: factors contributing to stalemate and potential political change in Puerto Rico and US Virgin Islands. In P. Clegg \& E. Pantojas-García (Eds.), Governance in the non-independent Caribbean (pp. 45-60). Kingston, Jamaica: Ian Randle Publishers.

Saba News (2014, December 18). Insufficient voters referendum Statia. Retrieved from http://www.saba-news.com/insufficient-voters-referendum-statia/

Scheepmaker, M. P. C. (2009). Voorwoord. Justitiële Verkenningen, 5, 5-9.

Sedoc-Dahlberg, B. (1990a). Suriname: 1975-1989. Domestic and foreign policies under military and civilian rule. In B. Sedoc-Dahlberg (Ed.), The Dutch Caribbean: Prospects for democracy (pp. 17-34). New York: Gordon and Breach.

Sedoc-Dahlberg, B. (Ed.). (1990b). The Dutch Caribbean: Prospects for democracy. New York: Gordon and Breach.

Stuart, K. (2009). The world's populated sub-national island jurisdictions. In G. Baldacchino \& D. Milne (Eds.), The case for non-sovereignty (pp. 11-20). London: Routledge.

Sutton, P. (2007). Democracy and good governance in small states. In E. Kisanga \& S. J. Danchie (Eds.), Commonwealth small states. Issues and prospects (pp. 201-217). London: Commonwealth Secretariat.

Sutton, P. (2009). Non-independent territories and small states: Retrospect and prospect. In P. Clegg \& E. Pantojas-García (Eds.), Governance in the non-independent Caribbean (pp. xxiii-xlv). Kingston, Jamaica: Ian Randle Publishers.

Thorndike, T. (1990). Suriname and the military. In B. Sedoc-Dahlberg (Ed.), The Dutch Caribbean: Prospects for democracy (pp. 35-62). New York: Gordon and Breach.

Van den Bor, W. (1979). Eiland op drift. De sociale organisatie van een kleine Caribische samenleving: St. Eustatius. Wageningen: Landbouwhogeschool.

Veenendaal, W. (2013a). Size and personalistic politics: Characteristics of political competition in four microstates. The Round Table, 102(3), 245-257.

Veenendaal, W. (2013b). Size and institutional legitimacy: The case of St. Kitts and Nevis. Commonwealth and Comparative Politics, 51(3), 343-361.

Veenendaal, W. (2014). Politics and democracy in microstates. London: Routledge.

Veenendaal, W., \& Corbett, J. (2014). Why small states offer important answers to large questions. Comparative Political Studies, 48(4), 527-549.

Verton, P. (1973). Kiezers en politieke partijen in de Nederlandse Antillen. Aruba: De Wit.

Watts, R.L. (2009). Island jurisdictions in comparative constitutional perspective. In G. Baldacchino \& D. Milne (Eds.), The case for non-sovereignty (pp: 21-39). London: Routledge. 